\title{
Epistemic, Evaluative, Speech Act Adverbs and Italian Political Language*
}

\author{
Francesca La Forgia (Bologna)
}

\begin{abstract}
This paper focuses on a group of Italian adverbs ending in -mente whose general function is to convey the speaker/writer's stance towards what is being said or written: Its purpose is to offer a preliminary description of how epistemic, evaluative and speech act adverbs are used in a specific genre of political discourse: parliamentarians' speeches during sessions of the Assemblea of the Italian Chamber of Deputies. Since these speeches have an argumentative communicative intention and are highly planned texts, they constitute a potentially favourable environment to observe how these adverbs contribute to building the argumentation, handling agreements and disagreements, and supporting or rejecting opinions.

More precisely, I will analyse epistemic adverbs that express doubt and certainty, such as probabilmente ('probably') and certamente ('certainly'); epistemic adverbs that express the source of knowledge, such as ovviamente ('obviously') and evidentemente ('evidently'); evaluative content-oriented adverbs like sfortunatamente ('unfortunately'); participant-oriented adverbs like giustamente ('justly'/'rightly'); and speech act adverbs such as francamente ('frankly').
\end{abstract}

\section{$1 \quad$ Introduction}

This paper focuses on a particular group of Italian adverbs formed with the suffix -mente (equivalent to the English: suffix -ly) and generally labelled as sentence adverbs (or sentence adverbials), insofar as their scope extends to whole sentences affecting, in different ways, their propositional content. More precisely, my analysis will focus on the following three (sub-)classes of sentence adverbs:

- adverbs such as certamente, evidentemente, ovviamente, probabilmente ('certainly', 'evidently', 'obviously', 'probably') whose function is to express the speakers/writers' degree of certainty (or uncertainty) about what they are saying or writing;

- adverbs such as (s)fortunatamente, intelligentemente, gentilmente ('(un)fortunately', 'intelligently', 'kindly') whose function is to express the speakers/writers' attitude towards the propositional content;

\footnotetext{
* I would like to thank the two referees for their valuable advice. All the remaining errors and inaccuracies are to be exclusively ascribed to the writer.
}

Linguistik online 92, 5/18 - http://dx.doi.org/10.13092/lo.92.4508

CC by 3.0 
- adverbs such as francamente, onestamente ('frankly', 'honestly') whose function is to express the speakers/writers' comments on "the manner of conveying the message" (Biber et al. 1999: 857).

The purpose of this paper is to offer an initial description of how these adverbs are used in a specific genre of political discourse: parliamentarians' speeches during sessions of the Assemblea of the Italian Chamber of Deputies. ${ }^{1}$

I have chosen parliamentarians' speeches for four reasons. The first one is of a practical nature, that is to say, easy access and availability of data: anything that is said and takes place during the Assemblea is faithfully transcribed in the Stenographic Report, which published in the Chamber's website immediately after the end of a session (cf. CAMERA IT 2015). The other three reasons are, however, of a more substantial nature: i) these speeches have an argumentative and communicative intention - that is to say, they are argumentative text-type (cf. Hatim 1984); ii) almost all the speeches feature a highly planned talk, as their core is based on a written text to be pronounced; and iii) each session of the Assemblea is, as a whole, a pluralist debate about a given topic consisting of a series of monologues (cf. Santulli 2005). Thus, it is very common to find intertextual references to what has been said by others with explicit realisation of agreement and disagreement within each speech.

These last three characteristics make this textual/discursive genre a potentially favourable environment for using the adverbs being analysed here. In particular, since these texts/speeches are highly planned, they are sufficiently structured and organised to observe how these adverbs contribute to building the argumentation, handling agreements and disagreements, and supporting or rejecting opinions.

In order to clarify my approach, in section 2 I will describe my theoretical framework of reference (cf. Prandi 2004), and the general classification of adverbs based on Michele Prandi's grammar (2006) and his paper on adverbs (2007). I will subsequently define the above three (sub-)classes, mainly using the descriptions drafter by Biber et al. (1999) and Ramat/Ricca (1998). In section 3, I will discuss the relevant features of the texts/speeches contained in the corpus and will provide some raw data on the occurrences of the adverbs ending with the suffix -mente that can be included into the three (sub-)classes. Finally, in sections 4 and 5, I will analyse how these adverbs are used in parliamentarians' speeches, in order to observe how they contribute to develop argumentative moves.

\footnotetext{
${ }^{1}$ The word Assemblea is translated as "Floor of the House" in the English version of the Chamber's official website: "The centre of activities of the Chamber of Deputies is the Floor of the House, which is where major decisions are made, debates are held on the items on the Chamber of Deputies' agenda, most legislative bills are discussed and voted on, confidence in the Government is granted or revoked, policy-setting acts (motions and resolutions) are discussed and questions and interpellations are made" (CAMERA EN 2015). The English expression is taken from the UK Parliament where it refers "to the main Chamber in each House. Business that is taken on the floor of the House is dealt with in the Chamber as opposed to being debated in a committee room" (UK PARLIAMENT).
} 


\section{Theoretical Framework and Classification of Sentence Adverbs}

Before describing the theoretical framework I have used and providing a classification of the adverbs, terminological issue, closely related to two facts, must be addressed.

Firstly, adverbs can occupy available positions inside a simple or complex clause. Therefore, the extent of their semantic effect can vary depending on their distribution inside the clause. They can perform different functions. More precisely, an adverb can extend to three different levels: a) the immediate constituents of the clause; b) the whole sentence; c) the utterance. At the level of immediate constituents, an adverb, for instance, can be placed inside a verb phrase thus specifying the manner in which an action is performed: Camminava velocemente ("S/he walked quickly'). At the level of the whole sentence, an adverb can add, for instance, a temporal framework to an action/event (whole clause): Ieri, ha piovuto ('Yesterday, it rained'). Finally, at the level of the utterance, an adverb can affect the propositional content of a clause, expressing, for instance, the degree of certainty regarding what is said: Probabilmente, non $\grave{e}$ in casa ('Probably, s/he is not at home').

Secondly, not only can the same adverb convey a different function depending on its syntactic position, but also (almost) all the functions performed by adverbs can be performed by other linguistic elements that do not share their morphological form, and can have a different syntactic distribution.

As well as the term "adverb", scholars have begun to use the term "adverbial" in an attempt to account for this variation. For instance, in De Cesare (2016), the noun "adverbial" can refer to a syntactic function, identifying a non-argumental constituent of the clause, whereas the term "adverb" refers to a word class identified by morphological features. An adverb is the prototypical realisation of an adverbial, but is not the only one: an adverbial of predicate can, for instance, be expressed by an adverb of manner such as quickly, or by a prepositional phrase such as in a hurry: S/he left quickly/in a hurry (cf. De Cesare 2016: 28). In Biber et al., instead, the noun "adverbial" identifies a difference at a distribution syntactic level. The term "adverb" refers to forms that "can [...] be integrated into an element of the clause" (i.e. a constituent of the clause), while the noun "adverbial" refers to forms that "function as an element of the clause" (Biber et al. 1999: 538). The function of adverbs is to modify the meaning of the element, be it a verb, an adjective or another adverb. Adverbials, instead, can convey "three major functions": "to add circumstantial information about the proposition in the clause, to express speaker/writer stance towards the clause, or to link the clause (or some part of it) to some other unit of discourse" (Biber et al. 1999: 762).

In both descriptions, the term "adverbial" allows to put the morphological aspect in the background (in relation to the fact that, traditionally, "adverb" as a label identifies a lexical class, i. e. a part of speech), and allows to elaborate a classification based on syntactic and functional criteria. However, precisely because the term "adverbial" emphasises the syntactic level too much, in this paper, following the Italian tradition, I will use "adverbial" as an adjective, and the pair "adverb/adverbial locution" (i. e. adverbial expression) to identify a morphological difference. Traditionally, in the literature focusing on Italian, the term "adverb" includes the following invariable words: 
- Simple words such as qui, ora, forse, etc. ('here', 'now', 'peraphs');

- Compound words such as tuttavia, dappertutto, etc. ('nevertheless', 'evrywhere');

- Words formed with the suffix -mente, such as velocemente, naturalmente, saggiamente, etc. ('quickly', 'naturally', 'wisely').

Instead, "adverbial locution" includes all the complex expressions formed by more than one word that, regardless of their morphosyntactic form, perform the functions attributed to the class of adverbs, and have the same distribution (cf. Serianni 1989: 491; Lonzi 1991: 341; Prandi 2007: 92-94):

- Prepositional phrases, such as con attenzione, di notte, etc. ('with care', 'at night');

- Fixed phrases that can be prepositional phrases, such as a stento ('barely'/'hardly'), di bene in meglio ('better and better'), d'ora in poi ('from now on');

- Fixed phrases that are obtained by doubling a noun, an adjective or an adverb, such as passo passo ('step by step'), bel bello (literally 'nice nice' meaning: 'without a care'), quasi quasi (literally 'almost almost');

- Clauses, such as come ho detto ('As I said'), per essere sincero ('to be honest'), politicamente parlando ('politically speaking'), etc.

This distinction, based on morphological features, is the most consistent with Prandi's theoretical description of language. Combining the structuralist and the functionalist paradigm and using Halliday's three "basic functions of language" (i.e., ideational, textual and interpersonal (Halliday 1970: 142)), Prandi's theoretical framework aims at describing how a language construct and expresses complex meanings. The difference between building and expressing refers to the difference in coding the meaning: a distinction between relational coding and punctual coding (cf. Prandi 2004).

Relational coding operates within the clause core (or nuclear sentence) that is composed of the verb and its arguments (i.e., the linguistic expressions that saturate the valencies of the verb). This coding is based on a network of grammatical relations that builds meaning irrespective of the conceptual content of the elements involved, i.e., coding stretches from form to content, and fulfils the ideational function. The punctual coding, however, operates outside the clause core and is used to add other elements - called margins - that are meant to enrich the simple process built through the relational coding. Margins are connected to the clause by virtue of their conceptual content, i.e., moving from content to form whereas punctual coding is based on a network of conceptual relations that uses linguistic forms to express a specific conceptual content consistent with the clause core. Depending on its distribution inside the clause and its conceptual content, a margin can fulfil all the three basic functions. 2

The space in which relational coding operates can also be defined as the space of rules: the core of a clause can only be built using syntactic devices offered by a language to link the

\footnotetext{
2 In Prandi's words (2004: 61-62): "Relational coding depends on the presence of an independent network of grammatical relations. In the presence of relational coding, a given phrase - for instance, a noun phrase - encodes a given role - for instance, the agent - not in isolation, but as a term of a grammatical relation - typically, as subject or object. Punctual coding operates outside the network of grammatical relations. In the presence of punctual coding, a given expression is connected to a given role not as a term of a grammatical relation but in isolation. [...]. Expressions located outside the network of grammatical relations [...] are defined, identified, and connected to the syntactic structure of the sentence thanks to their association with a substantive content of role."
} 
verb and its arguments. The space in which the punctual coding operates, however, is the space of the options: the speaker is free to choose the most suitable linguistic form to express a given conceptual content. At the theoretical level of describing languages, it means that we can distinguish between a "grammar of rules" and a "grammar of options" (Halliday 1978: 4).

Within the realm of a grammar of rules, grammatical forms and constructions are primitive terms, to be taken just as they are and described through internal, formal criteria. Within the realm of a grammar of options, one has first to identify a set of conceptual structures and then describe each in autonomous conceptual terms. It is only at this point that circumscribing sets of heterogeneous grammatical resources as alternative means for bringing a given concept to expression makes sense.

(Prandi 2004: XV)

This theoretical approach is particularly suitable to describe Italian adverbs, because almost all of them are margins and, hence, their description pertains to a grammar of options. ${ }^{3}$ As margins, adverbs are just one of the options that speakers/writers can use to express a given conceptual content. That is the reason why almost all the syntactic-semantic functions expressed by adverbs can also be performed by other linguistic forms. Some of these linguistic forms can be classified as adverbial locution (e.g. the prepositional phrase in a hurry), others cannot. For instance, the speaker/writer's degree of certainty towards what is being said/written can be expressed by the adverb probably or by the verb could (Probably, s/he is at home; S/he could be at home). Could does not share the same syntactic distribution as probably; it is not another means to fulfil a syntactic function. It is simply another option to express the same conceptual structure. That is the reason why I prefer to use the pair "adverbs/adverbial locutions" based on morphological features rather than the noun "adverbials" that, as I have already stated, emphasises the syntactic dimension too much.

Using Halliday's three basic functions as the main criterion, Prandi's classification makes it possible to start from the definition of broad and widely shared conceptual structures. It is only on the basis of this definition that linguistic forms that can express them and are defined with criteria related to their semantic and syntactic functions can be identified. Prandi's classification can be outlined as in Table 1 (cf. Prandi 2006: 325-330; 2007: 94-99). The adverbs analysed by this paper are those that perform the interpersonal function ${ }^{4}$ (modal, evaluative, and utterance adverbs). These adverbs (and adverbial locutions) are used to establish a relationship between speaker/writer and listener/reader through language. Their general semantic

\footnotetext{
${ }^{3}$ Only adverbs (and adverbial locutions) conveying space and time-related information can be both arguments of the verb and margins. As verb's arguments, they are connected to the clause core by relational coding; as margins, they are connected by punctual coding. In a clause like S/he lives here, the adverb here is an argument of the verb (i.e. it is required by the verb to saturate its valency). However, in a clause like S/he teaches literature here, the adverb here is a margin that provides the spatial setting for the process built by the verb. The difference is that a margin can be taken outside the core clause (S/he teaches literature. It happens here), while a verb's argument cannot $(*$ S/he lives. It happens here). In the following classification, I will only take adverbs (and adverbial locutions) that are margins into account.

4 In Halliday's words (1970: 143): "Language serves to establish and maintain social relations: for the expression of social roles, which include the communication roles created by language itself [...]; and also for getting things done, by means of the interaction between one person and another. Through [interpersonal] function, [...] social groups are delimited, and the individual is identified and reinforced, since by enabling him to interact with others language also serves in the expression and development of his own personality".
} 
function is to make explicit, at various degree, the speaker/writer's stance towards the propositional content of an utterance.

\begin{tabular}{|c|c|c|c|}
\hline $\begin{array}{l}\text { Halliday's } \\
\text { Functions }\end{array}$ & $\begin{array}{l}\text { Conceptual/Semantic Func- } \\
\text { tion }\end{array}$ & Syntactic Function & $\begin{array}{l}\text { Adverbs (and Adver- } \\
\text { bial Locutions) }\end{array}$ \\
\hline \multirow{4}{*}{$\begin{array}{l}\text { Ideational } \\
\text { Function }\end{array}$} & $\begin{array}{l}\text { Expresses the manner in } \\
\text { which an action is per- } \\
\text { formed }\end{array}$ & Verb's Modifiers & $\begin{array}{l}\text { Se ne andò velocemen- } \\
\text { te/in fretta } \\
\text { [S/he left quickly/in a } \\
\text { hurry] }\end{array}$ \\
\hline & $\begin{array}{l}\text { Amplifies or diminishes the } \\
\text { meaning conveyed by an } \\
\text { adjective (intensifi- } \\
\text { ers/downtoners) }\end{array}$ & $\begin{array}{l}\text { Adjective's Modi- } \\
\text { fiers }\end{array}$ & $\begin{array}{l}\grave{E} \text { molto/abbastanza } \\
\text { buono } \\
\text { [It is very/quite good] }\end{array}$ \\
\hline & $\begin{array}{l}\text { Amplifies or diminishes the } \\
\text { meaning conveyed by the } \\
\text { adverb (intensifi- } \\
\text { ers/downtoners) }\end{array}$ & Adverb's Modifiers & $\begin{array}{l}\text { Se ne andò molto ve- } \\
\text { locemente } \\
\text { [S/he left very quickly] }\end{array}$ \\
\hline & $\begin{array}{l}\text { Adds temporal information } \\
\text { Adds spatial information }\end{array}$ & $\begin{array}{l}\text { Circumstance Ad- } \\
\text { verbs/Adverbial } \\
\text { Locutions }\end{array}$ & $\begin{array}{l}\text { Ieri, l'albero cadde } \\
\text { [Yesterday, the tree } \\
\text { fell] } \\
\text { L'albero è caduto } \\
\text { qui/in questo luogo } \\
\text { [The tree fell here/in } \\
\text { this place]. }\end{array}$ \\
\hline $\begin{array}{c}\text { Ideational + } \\
\text { Textual } \\
\text { Function }\end{array}$ & $\begin{array}{l}\text { Expresses the conceptual } \\
\text { relationship between } \\
\text { clauses, sentences, or be- } \\
\text { tween larger section of a } \\
\text { text/speech }\end{array}$ & $\begin{array}{l}\text { Interclausal or Tex- } \\
\text { tual Links }\end{array}$ & $\begin{array}{l}\text { Sono stanco, per- } \\
\text { ciò/per questo motivo } \\
\text { non esco } \\
\text { [literally: I am tired } \\
\text { therefore / for this } \\
\text { reason I am not going } \\
\text { out] }\end{array}$ \\
\hline $\begin{array}{l}\text { Textual } \\
\text { Function }\end{array}$ & $\begin{array}{l}\text { Modifies the communication } \\
\text { perspective, highlighting an } \\
\text { element of the clause }\end{array}$ & Focus Adverbs & $\begin{array}{l}\text { Solo lui/lei gioca a } \\
\text { pallone } \\
\text { [Only s/he plays foot- } \\
\text { ball }] \\
\text { Ha anche bevuto } \\
\text { [S/he also drank }]\end{array}$ \\
\hline
\end{tabular}


Francesca La Forgia: Epistemic, Evaluative, Speech Act Adverbs and Italian Political Language151

\begin{tabular}{|c|c|c|c|}
\hline & $\begin{array}{l}\text { Identifies "a referential or } \\
\text { semantic (or notional) do- } \\
\text { main relevant to the descrip- } \\
\text { tion of a state, process, etc. } \\
\text { encoded in a proposition" } \\
\text { (De Cesare et al. forth- } \\
\text { coming) }\end{array}$ & $\begin{array}{l}\text { Domain Ad- } \\
\text { verbs/Adverbial } \\
\text { Locutions }\end{array}$ & $\begin{array}{l}\text { Politicamente (par- } \\
\text { lando), è la scelta } \\
\text { sbagliata } \\
\text { [Politically (speaking), } \\
\text { this is the wrong } \\
\text { choice] }\end{array}$ \\
\hline $\begin{array}{l}\text { Textual }+ \\
\text { Interpersonal } \\
\text { Function }\end{array}$ & $\begin{array}{l}\text { Expresses the organization } \\
\text { of text/speech } \\
\text { Expresses a metatextual, } \\
\text { metalinguistic, or meta- } \\
\text { communicative function, } \\
\text { introducing a reformulation } \\
\text { or an example }\end{array}$ & Discourse Markers & $\begin{array}{l}\text { Innanzitutto/in primo } \\
\text { luogo vorrei ringra- } \\
\text { ziare... } \\
\text { [Firstly/first of all I } \\
\text { would like to thank...] } \\
\text { e.g. cioè, in altre paro- } \\
\text { le,per esempio, etc. } \\
{[\text { namely, in other }} \\
\text { words, for instance }]\end{array}$ \\
\hline \multirow[t]{3}{*}{$\begin{array}{l}\text { Interpersonal } \\
\text { Function }\end{array}$} & $\begin{array}{l}\text { Conveys the } \\
\text { speaker/writer's stance } \\
\text { and/or commitment towards } \\
\text { what is being said or written }\end{array}$ & $\begin{array}{l}\text { Modal Ad- } \\
\text { verbs/Adverbial } \\
\text { Locutions }\end{array}$ & $\begin{array}{l}\text { e.g.necessariamente, } \\
\text { senza dubbio, ovvia- } \\
\text { mente, forse etc. } \\
\text { [Necessarily, no } \\
\text { doubt, obviously, per- } \\
\text { haps] }\end{array}$ \\
\hline & $\begin{array}{l}\text { Expresses the } \\
\text { speaker/writer's attitude } \\
\text { towards the propositional } \\
\text { content }\end{array}$ & $\begin{array}{l}\text { Evaluative Ad- } \\
\text { verbs/Adverbial } \\
\text { Locutions }\end{array}$ & $\begin{array}{l}\text { e.g. } \\
(\text { s)fortunatamentelper } \\
\text { fortuna, intelligente- } \\
\text { mente, etc. } \\
{[(\text { Un)fortunately, intel- }} \\
\text { ligently] }\end{array}$ \\
\hline & $\begin{array}{l}\text { Comment "on the manner of } \\
\text { conveying the message" } \\
\text { (Biber et al. 1999: 857) }\end{array}$ & $\begin{array}{l}\text { Utterance Ad- } \\
\text { verbs/Adverbial } \\
\text { Locutions }\end{array}$ & $\begin{array}{l}\text { e.g. sinceramente/per } \\
\text { essere sincero, fran- } \\
\text { camente, etc. } \\
\text { [Honestly/to be honest, } \\
\text { frankly] }\end{array}$ \\
\hline
\end{tabular}

Table 1: General Classification of Adverbs and Adverbial Locutions Based on Prandi's Works (2006; 2007)

In order to achieve a more detailed description, I combined Prandi's description with Biber et al.'s classification, ${ }^{5}$ modifying the labels and/or the descriptions of the three (sub-)classes.

\footnotetext{
5 In Biber et al.'s description, these three (sub-)classes are included under the label called "stance adverbials". I have already discussed the use of the noun "adverbial" to differentiate adverbs occurring inside another ele-
} 
More specifically, I have labelled the first (sub-)class "epistemic adverbs", because I am analysing only those adverbs whose semantic function is to express the speaker/writer's degree of certainty towards the propositional content of the sentence. This means that I will not take into account adverbs expressing a deontic modality such as obbligatoriamente or tassativamente ('obligatory' or 'compulsorily'), or adverbs expressing an alethic modality, i. e. "a necessary truth" (Cinque 1999: 78; emphasis in the original). ${ }^{6}$ Following Biber et al.'s classification, my first (sub-)class of adverbs can be described as follows:

- Epistemic adverbs and adverbial locutions commenting on the propositional content of a sentence, expressing the speaker/writer's "judgment about the certainty [and] reliability [...] of the proposition" (Biber et al. 1999: 854). They can express (Biber et al. 1999: 854-855):

- Doubt and certainty: forse, probabilmente, certamente, senza dubbio, indubbiamente, etc. ('perhaps', 'probably', 'certainly', 'no doubt', 'undoubtedly');

- Actuality and reality: effettivamente, di fatto, realmente, etc. ('actually', 'in fact', 'really');

- Source of knowledge: ovviamente, evidentemente, apparentemente, come dice $x /$ come è riportato in $x$, etc. ('obviously', 'evidently', 'apparently', 'according to $\mathrm{x} /$ reportedly');

- Viewpoint or perspective: personalmente, secondo me/noi/voi, dal mio/nostro/vostro punto di vista, etc. ('personally', 'in my/our/your opinion', 'from my/our/your perspective'). ${ }^{7}$

For the second (sub-)class, I have kept Prandi's label "evaluative adverbs" (in Biber et al. this class is labelled "attitude adverbials"), but I distinguish between event-oriented and participant-oriented adverbs (cf. Ramat/Ricca 1998: 190):

- Evaluative adverbs and adverbial locutions express the speaker/writer's "attitude towards the proposition typically conveying an evaluation, value judgement, or assessment of expectations" (Biber et al. 1999: 856). In order to do so, they must assume the truth of the proposition (i. e. the propositional content must be considered as a presupposition):

- Event-oriented adverb and adverbial locutions comment on the event expressed by the proposition: incredibilmente, (s)fortunatamente, per fortuna, etc. ('incredibly', '(un)fortunately', 'by good fortune');

\footnotetext{
ment of the clause from adverbs that are themselves clause elements. The term "stance", however, is used to identify "adverbials [that] convey speakers' comments on what they are saying (the content of the message) or how they are saying it (the style). Stance adverbials fall into three categories: epistemic, attitude, and style" (Biber et al. 1999: 764; emphasis in the original).

${ }^{6}$ For a description of the difference between epistemic and deontic modality in English and in Italian, see Cinque (1999) and Pietrandrea (2004) respectively.

${ }^{7}$ In reality, Biber et al. identify other two areas of meaning: "limitation adverbials", that "mark the limitation of the proposition", and "imprecision adverbials", that "are used to show that the proposition being conveyed is somehow imprecise" (Biber et al. 1999: 854-855). Since both areas seem to refer to a textual or a metacommunicative dimension rather than an epistemic modality, I have excluded them.
} 
- Participant-oriented adverb and adverbial locutions comment on the subject's behaviour: intelligentemente, correttamente, stupidamente, giustamente, etc. ('intelligently', 'correctly', 'stupidly', 'justly').

Finally, I have labelled the third (sub-)class "speech act adverbs" (Prandi 2007: 99 "utterance adverbs"; Biber et al. 1999: 764 "style adverbials"). They include:

- Speech act adverbs and adverbial locutions that comment on "the speech act associated with the sentence" (Ramat/Ricca 1998: 190). They can be:

- Speaker-oriented: francamente, sinceramente, per essere sincero/franco, etc. ('frankly', 'honestly', 'to be honest');

- Speech act-oriented: brevemente, in breve ('briefly', 'in short') (cf. Dik et al. 1990: 38) ${ }^{8}$

As has already been stated at the beginning of this paper, my analysis focuses on the adverbs ending in -mente; however, in some cases, I have also taken into account adverbial locutions and simple adverbs such as forse ('perhaps') and purtroppo ('unfortunately') in order to describe more accurately the behaviour of the adverbs under analysis.

\section{Parliamentarians' Speeches and Epistemic, Evaluative and Speech Act Adverbs}

In the introduction, I defined parliamentarians' speeches as a textual/discursive genre by implicitly identifying a specific class of texts/speeches different from all other political texts/speeches. Parliamentarians' speeches can be considered a textual/discursive genre only if the sessions of the Assemblea of the Chamber of Deputies are considered as individual communicative events. In this regard, parliamentary speeches, as a genre, identify all those texts/speeches pronounced by parliamentarians or Government representatives during sessions of the Assemblea of the Chamber of Deputies (as well as of the Senate). However, during a session of the Chamber, several things can "happen", i. e. we can identify several communicative sub-events corresponding to different forms of parliamentary speeches. More specifically, the following sub-events are the most significant ones according to my analysis:

- Debates: where deputies entitled to speak (as they have previously registered in a specific register) discuss the general lines of a bill or a motion (the maximum standard duration of a speech is 30 minutes).

- Explanations of vote: where deputies entitled to speak declare how the group/party they belong to will vote on a bill.

- Questions: where, on request of one or more parliamentarians, a Government representative informs deputies on the content of the question during a plenary session.

The first two sub-events are a pluralist debate consisting of a series of monologues on the same topic, whereas the last one is almost like a dialogue. Almost is the key word, since, in this situation, it is the President who decides who shall take the floor on the basis of the Rules

\footnotetext{
8 According to Conte (1999: 49), brevemente is rather an "avverbio testuale" ('textual adverb') than a speech act adverb, because it conveys information about the function and position of a sentence inside a text: "Gli avverbi [testuali] concernono non l'enunciazione di un enunciato, ma la funzione e la posizione d'un enunciato (o d'una sequenza di enunciati) in un testo. In altri termini, essi sono indicatori testuali che danno istruzioni sullo statuto testuale di ciò che segue."
} 
of Procedure. However, in accordance with the Rules of Procedure, the question is structured as follows: a parliamentarian poses his/her question; a Government representative answers; the parliamentarian is allowed to reply (this is a technical term) for a maximum of 5 minutes. At least in theory, the reply is an immediate reaction to what was said and, as a consequence, can be a spontaneous speech.

The analysis was conducted on 50 stenographic reports (for a total of 1,558,594 tokens and 40,731 types) from January 2007 to November 2014. I initially created a (non-exhaustive) list of adverbs ending with the suffix -mente, starting from the ones listed by Prandi $(2006,2007)$. I subsequently expanded such a list on the basis of other studies (in particular, Venier 1991 and Ramat/Ricca 1998) and Italian monolingual dictionaries (in particular Treccani [s.a.] and De Mauro [2001]). The following table (Table 2) contains the results of this first research. Adverbs have been broken down based on the parameters described at the end of the previous paragraph with the corresponding absolute number of occurrences (RwOcc. is an abbreviation for Raw Occurrences) and the number of occurrences of adverbs in absolute initial position (Init.Pos is an abbreviation for Initial Position). The expression "absolute initial position" means that the adverb occurs after a full stop and, therefore, it appears in the initial position of a new sentence, thus making it possible to use an objective criterion to reduce the number of occurrences and simplifying an accurate analysis of the examples. Many of these adverbs, in fact, can also fulfil other semantic functions; and even if the absolute initial position is the prototypical position in which the semantic effect of these adverbs can extend to the whole sentence, they might convey a different semantic function. For instance, ovviamente and evidentemente ('obviously' and 'evidently') can be used together with yes or no in order to intensify agreement or disagreement:

\section{A: Sei d'accordo 'Do you agree?'}

B: Ovviamente (sì)/Ovviamente no 'Obviously (yes)/Obviously I do not'

Very often, adverbs such as effettivamente and realmente ('actually' and 'really') are used as intensifiers just like molto ('much') (cf. De Cesare 2003). In a sentence like Francamente, $t i$ ha già risposto (literally: 'Frankly, s/he has already answered you'), the adverb does not mean 'I am being frank when I say...', and, therefore, does not behave as a speech act adverb. It functions as a discourse marker, something like guarda che ti ha già risposto (literally, 'looks like s/he has already answered you'). At the same time, as we will see in $\S 5$, an internal position, for instance after a verb, does not necessarily mean that the adverb functions as a modifier.

\begin{tabular}{|c|c|c|c|c|}
\hline Class & $\begin{array}{l}\text { Functional/Semantic } \\
\text { Layers }\end{array}$ & Adverbs & RawOcc & Init.Pos \\
\hline \multirow{5}{*}{$\begin{array}{l}\text { Epistemic } \\
\text { Adverbs }\end{array}$} & \multirow[t]{5}{*}{ Doubt and Certainty } & Certamente [Certainly] & 519 & 65 \\
\hline & & Sicuramente [Surely] & 422 & 28 \\
\hline & & Probabilmente [Probably] & 276 & 26 \\
\hline & & Indubbiamente [Undoubtedly] & 43 & 7 \\
\hline & & Possibilmente [Possibly] & 10 & 0 \\
\hline
\end{tabular}


Francesca La Forgia: Epistemic, Evaluative, Speech Act Adverbs and Italian Political Language155

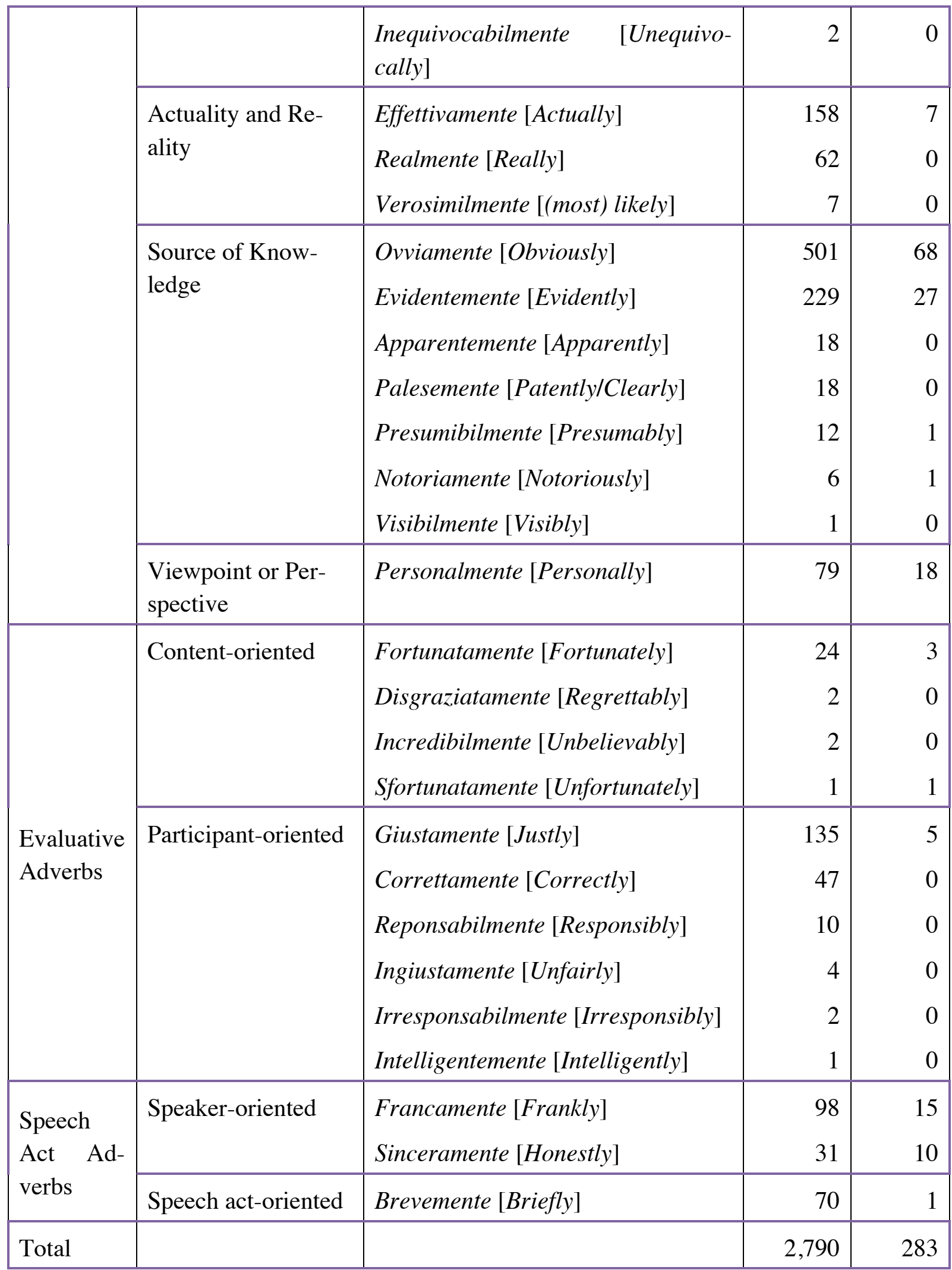

Table 2: Raw Occurrences of Adverbs ending in -mente

Based on the data recorded, we can make some preliminary observations concerning the three (sub-)classes.

First of all, five epistemic adverbs belonging to two of the four semantic areas that have been identified account for the higher number of absolute occurrences. Certamente ('certainly', 
519 occurrences), sicuramente ('surely', 422) and probabilmente ('probably', 276) allow a speaker to express the degree of certainty attributed to what s/he is saying. Ovviamente ('obviously', 501 occurances) and evidentemente ('evidently', 229), however, allow the speaker to refer to the type of source on which what s/he is saying is based. Actually, total occurrences of these five adverbs $(1,947)$ accounts for almost $70 \%$ of the total occurrences of adverbs searched for $(2,790)$. These data are in line with what was assumed at the beginning: in argumentative text-types, expressing the degree of certainty of a statement or relying on a widely known or obvious source can help persuade listeners about the validity of what a speaker is saying. This can also explain fewer occurrences of probabilmente ('probably') and just 10 of possibilmente ('possibly'), since something which is possible is less certain than something which is probable which, in turn, is less certain than what is certain. If we take into account the 633 occurrences of the simple adverb forse ('perhaps'), the difference between the area of certainty and the area of doubt decreases considerably: 986 occurances of adverbs expressing certainty (certamente 'certainly', sicuramente 'surely', indubbiamente 'undoubtedly', inequivocabilmente 'unequivocally') against 919 occurrences for the area of less certainty or doubt (probabilmente 'probably', possibilmente 'possibly', forse 'perhaps'). It is clear that this observation should be supported by further analysis by drawing up a more thorough list of adverbs and adverbial locutions on the one hand, and by observing whether there are distributional differences related to the propositional content on the other hand (cf. $\S 4$ ).

Explaining the fewer occurrences of indubbiamente ('undoubtedly') is more difficult. Even if we sum up the 15 occurrences of the adverbial locution senza (alcun) dubbio ('no doubt') and the 35 occurrences of the clause non vi/c'è dubbio ('there is no doubt that'), the total number of occurrences (93) is still far from the total sum of other adverbs expressing certainty. We may assume that parliamentarians prefer using the semantic area of doubt in order to express the existence (for instance, $c i$ sono dei dubbi [literally: 'there are some doubts']) rather than the absence of a doubt. This assumption, however, should be further investigated on texts.

The second observation concerns the higher frequency of ovviamente ('obviously') compared to evidentemente ('evidently'). Unlike the couple certamente/sicuramente ('certainly/surely'), which shares such a high number of semantic features to make them almost perfect synonyms, ovviamente, when compared to evidentemente, conveys a surplus of meaning. Something 'obvious' is so evident that everybody knows about it, whereas something 'evident' is potentially visible to everybody but not necessarily known by everybody. This surplus of meaning seems similar to that conveyed by the focus adverbs addirittura/persino compared to anche (La Forgia 2006); similar to addirittura/persino, ovviamente goes beyond a threshold: a fact, an event or a consequence is so evident that it is obvious. It is clear that in argumentative texts, such a surplus of meaning is suitable for a "manipulative" use (Venier 1991: 117), i. e. to (let's say, exponentially) increase the evidence of what the speaker has stated (cf. Merlini Barbesi 1987). ${ }^{9}$

The third observation concerns the fact that, in these texts, content-oriented and participantoriented evaluative adverbs ending in -mente are used to express positive judgements; in order

\footnotetext{
${ }^{9}$ Note that epistemic adverbs expressing doubt and certainty are also suitable for a manipulative use.
} 
to express a negative judgement, the adverb purtroppo ('unfortunately'), which occurs 396 times, seems to be preferred. Moreover, the greater frequency of adverbs such as giustamente ('justly') and correttamente ('correctly') is consistent with the communicative situation: dealing with the legislative power, it is more important to define what is right and correct (from a normative and ethical perspective) than to judge whether someone has behaved in a smart or meaningless way. Conversely, the semantic field of "responsibility" is underrepresented: 10 occurrences for responsabilmente ('responsibly') and only 4 for its opposite irresponsabilmente ('irresponsibly').

The following two paragraphs will describe some particularly relevant phenomena: $\S 4$ will focus on epistemic adverbs conveying doubt, certainty, and source of knowledge whereas $\S 5$ will focus on both evaluative and speech act adverbs. For all the three (sub-)classes, the analysis was mainly carried out on those adverbs that appeared more than once in the absolute initial position. Every time there was a potentially interesting phenomenon, I tried to look for evidence by extending the analysis to other positions, other adverbs, and some adverbial locutions. The fact remains that the quantity of analysed data is not sufficient to define the general trends and therefore the following observations should be supported by further investigation.

\section{$4 \quad$ Epistemic Adverbs}

As an adverb used to convey the certainty of the propositional content of what is being said, in these texts certamente is used in absolute initial position with statements communicating facts (1). It is much more frequently used, though, to express the certainty of one's opinion on a specific topic (2), one's positions and expectations (3 and 4), and one's future or present behaviour (5).

1. Certamente nei Regolamenti [...] non vi è scritto nulla in merito [...]. $(\text { S260_18.12.07 })^{10}$ 'Certainly in the Rules of Procedure [...] there is nothing written about that.'

2. Certamente, vi è anche una patologia, perché nella legislazione complessa, ossia nell'intervento legislativo multilivello, molto spesso [...] il Governo [...] "la [fa] da padrone". (S228_22.10.07)

'Certainly, there is also a pathology, because in the complex legislation, that is, in multilevel legislative action, very often [...] the Government does what it wants.'

3. Certamente, ho apprezzato [...] il fatto che il Governo, attraverso la sua dichiarazione, abbia mantenuto un patto elettorale. (S101_31.01.07)

'Certainly, I appreciated the fact that the Government, through its declaration, has maintained an electoral pact.'

4. Certamente, avremmo preferito, $[\ldots]$, che la inammissibilità fosse stata valutata con maggiore attenzione [...]. (S101_31.01.07)

'Certainly, we would have preferred, [...], the inadmissibility to be assessed with greater attention $[\ldots]$.'

\footnotetext{
${ }^{10}$ Examples are referred to by means of session number (S260) and date (18.12.07). Unless otherwise specified, examples from the same session are taken from speeches by different speakers. Each example has been literally translated in order to maintain the adverb's position and the structure of Italian sentences.
} 
5. Siamo soddisfatti del lavoro svolto. Certamente, non ci fermiamo qui. (S258_14.12.07)

'We are satisfied with the work we have done. Certainly, we do not stop here.'

Other adverbs expressing certainty and doubt behave in a similar way, although they seem to show some preferences that should be further investigated in order to observe whether there are actually distributional differences or not. In the semantic area of certainty, sicuramente ('surely') and indubbiamente ('undoubtedly'), in absolute initial position, are primarily used to express certainty concerning a personal opinion (6 and 7), with a preference for indubbiamente to qualify opinions based on objective factual data (8), even when it occurs in a medial position and not in the absolute initial position (9).

6. Sicuramente poi i docenti [...] saranno ulteriormente penalizzati [...]. (S573_19.01.12)

'Surely then teachers will be further penalized [...].'

7. Indubbiamente la questione più rilevante per il nostro Paese, [...], è la salvaguardia dei buoni rapporti che intratteniamo con la Germania [...]. (S326_24.05.10)

'Undoubtedly the most important issue for our country, [...], is to protect the good relationships with Germany.'

8. Indubbiamente vi sono responsabilità europee, perché si tratta di un accordo europeo [...]. (S225_17.10.07)

'Undoubtedly there are European responsibilities, because this is a European agreement [...].'

9. Non siamo ancora alla moratoria, ma siamo indubbiamente di fronte a misure prese dal Governo cinese che segnano un cambiamento di quadro [...]. (S228_22.10.07)

'We are not yet in the moratorium, but we are undoubtedly facing measures taken by the Chinese government that overturn the situation [...]'

In the area of doubt, probabilmente ('probably') is used more frequently in sentences trying to interpret someone else's behaviour (10) and foreseeing the consequences of decisions and/or facts (11).

10. [...] siamo rimasti assolutamente sconcertati dal ritiro di quel decreto ministeriale [...]. Probabilmente, il Governo ha fatto alcune promesse, impegnandosi ad intervenire su questo fronte; [...]. (S101_31.01.07)

'[...] we were absolutely disconcerted by the withdrawal of that ministerial decree [...]. Probably, the Government has made some promises, committing itself to intervening on this matter $[\ldots]$ '

11. Probabilmente, se realmente si riuscirà a modificare il sistema elettorale, $[\ldots]$, i cittadini non potranno neanche scegliere chi li governa [...] (S228_22.10.07)

'Probably, if [the Government] really succeeds in changing the electoral system, [...], citizens will not even be able to choose who governs them [...]'

As for the area of adverbs which refer to the source of knowledge, it seems that evidentemente ('evidently') in absolute initial position occurs more frequently in sentences which propositional content communicating an interpretation of a fact or behaviour (examples 12-13), i. e. its behaviour seems similar to that of probabilmente. 
12. [...] non ci rifiutiamo di discutere sui punti di criticità del nostro sistema costituzionale, ma vogliamo farlo puntualmente, [...]. Evidentemente le opposizioni non vogliono attenersi a tali regole [...]. (S230_24.10.07)

'[...] we do not refuse to discuss the critical points of our constitutional system, but we want to do it rigorously [...]. Evidently the oppositions do not want to adhere to these rules $[\ldots]$ '

13. Speravamo che la questione si potesse risolvere in ambito politico-istituzionale. Evidentemente, in questa sede non siamo in condizioni di ottenere una risposta concreta. (S232_26.10.07)

'We hoped that the issue could be resolved in a political and institutional setting. Evidently, here we are not in a position to get a concrete answer.'

On the other hand, it seems that ovviamente ('obviously') occurs in positions which are more similar to those of certamente/sicuramente ('certainly/surely'), i. e. in sentences whose propositional content expresses facts and/or personal opinions (14), to state the obviousness of a personal position (15), an expectation (16) and future behaviour (17).

14. Questi fenomeni si manifestano sotto forma di erosioni, frane od alluvioni. Ovviamente tutto questo incide sulla vita umana [...]. (S311_16.10.14)

'These phenomena manifest themselves in the form of erosions, landslides or floods. Obviously all this affects human life [...].'

15. Ovviamente, non sono affatto soddisfatto della risposta del ministro Di Pietro [...]. (S101_31.01.07)

'Obviously, I am by no means satisfied with the response of Minister Di Pietro [...].'

16. Anche qui si apre una pagina di non sensi economici, giuridici e sociali. Ovviamente non viene fatto alcun investimento nel settore [...]. (S57_22.07.13)

'Here, too, there are many economic, legal and social nonsenses. Obviously no investment is being made in this area [...]'

17. Ovviamente - e concludo - ci riserviamo di intervenire in sede di discussione [...]. (S228_22.10.07)

'Obviously - and I conclude - we reserve ourselves the right to intervene during the discussion'

In other words, it seems that ovviamente might be interpreted not only as 'something is so evident as to be obvious', but also as 'something is so certain'/'sure as to be obvious'. This might also explain why the number of occurrences of ovviamente in twice that of evidentemente. However, to be certain, an analysis of each single example would be required.

Thus far, I have analysed epistemic adverbs taking into account the type of propositional content affected by their presence. However, broadening the perspective to interclausal relations, I would like to address adversative and causal syntactic structures associated with argumentative moves.

From an argumentative point of view, one of the communicative effects of an adversative structure is the mitigation of disagreement (Caffi 2009: 124-136), which is meant in a broad sense and is used, so to speak, to "concede a point" to the rival. Examples from (18) to (20) 
show cases in which the clause containing the epistemic adverb is followed by an adversative clause with $m a$ ('but'); whereas, in the examples from (21) to (23), the adverb occurs in the adversative clause. In all of these cases, a positive content is first expressed (examples 18, 19, and 23) or a wide sharing is granted (20,21 and 22), and immediately after (with the adversative) an element which can potentially create dissent is expressed. When the adverb occurs in the first clause, its function is to further weaken the potential disagreement; when, however, it appears in the adversative, it implies a kind of "half mitigation", because adverbs strengthen the position of dissent by giving it the basis of certainty or evidence. ${ }^{11}$

18. Certamente l'istituzione dell'Agenzia nazionale per i beni sequestrati e confiscati è avvenuta con i migliori intenti ma [i] risultati conseguiti nei primi quattro anni di operatività [...] sono tutt'altro che confortanti. (S246_16.06.14)

'Certainly the creation of the "Agenzia nazionale per i beni sequestrati e confiscati" was done with the best intent, but [the] achievements in this four years of activity [...] are far from comforting.'

19. Queste sono sicuramente alcune cose positive, ma ci sono anche molte cose negative che noi non ci sentiamo di condividere. (S57_22.07.13)

'These are surely some positive aspects, but there are also many negative aspects that we disagree with.'

20. Indubbiamente, il parlamentare deve rappresentare interessi anche [...] di categoria ma [...] sappiamo che, [...], deve rispondere alla propria coscienza [...]. (S101_31.01.07)

'Undoubtedly, the parliamentarian must also represent $[\ldots]$ corporate interests, but $[\ldots]$ we know that $[\ldots]$ he must respond to his conscience $[\ldots]$ '

21. [...] non so se tecnicamente la formulazione dell'articolo [...] sia la migliore possibile, ma certamente sollecita la pubblica amministrazione ad effettuare periodicamente una ricognizione dei reali fabbisogni, [...] (S226_18.10.07)

'I do not know if technically the wording of the article [...] is as good as possible/is the best possible solution, but it certainly urges the public administration to periodically check the real needs, $[\ldots]$ '

22. [...] manifestiamo la nostra vicinanza a tutti i militari italiani, ma non possiamo esimerci, ovviamente, dal trarre, [...], le nostre valutazioni [...]. (S005_27.03.13)

'[...] we feel close to all Italian soldiers, but we can not, obviously, exempt ourselves from drawing our own conclusions [...]'

23. Onorevole Ministro Mussi, la apprezzo per le cose che oggi ha detto - [...] - ma, evidentemente, c'è in discussione ben altro. (S266_15.01.08)12

'Mr Mussi, I appreciate the things you have said today - [...] - but, evidently, there is so much more at stake.'

\footnotetext{
${ }^{11}$ It is obvious that with an adverb like personalmente, the effect would be the opposite as it conveys a personal opinion: "Il Governo italiano con questo decreto-legge ha voluto probabilmente evitare che si inasprisse il contenzioso con la Germania, ma personalmente ritengo che esso sia criticabile sotto molteplici punti." (S326_24.05.10) 'The Italian government with this decreto-legge has probably wanted to prevent that the disagreement with Germany worsened, but personally I believe that it can be criticised in many ways'.

12 When it comes to show their dissent to what another speaker said or to what the Govern did, it seems that parliamentarians prefer more direct phrasing such as the ones referred to in examples (15) and (16).
} 
According to an argumentative perspective, the most interesting causal structure is the one expressing the reason why a statement has been made; when the adverb appears in the main clause (examples 24-26), ${ }^{13}$ the causal clause is used to explain both the reason underlying the statement and its certainty or evidence. On the contrary, when the adverb occurs in the causal clause (examples 27-29), the certainty or evidence underlying the reason is emphasised. For both structures, the effect is strengthening one's position/opinion.

24. E i consigli delle autonomie locali quando debbono eleggere i propri componenti? Certamente è un'operazione molto più lunga rispetto a quella del consiglio regionale, in quanto, di fatto, si tratta di un'elezione di terzo grado. (S230_24.10.07)

'And the local council when they have to elect their members? Certainly it is a much longer process than the election of the Regional Council, since, in fact, it is a "third degree election".'

25. Signor Presidente, signor ministro, ovviamente ci riteniamo assolutamente insoddisfatti, perché quello che lei ha enunciato in quest'aula è una parte di ciò che noi riteniamo essere la globalità delle azioni per le politiche della famiglia. (S101_31.01.2007)

'Mr President, Minister, obviously we are absolutely dissatisfied, because what you have said here is (just) a part of the actions we believe should be undertaken for family policies.'

26. Signor Presidente, se esiste tale dichiarazione, che evidentemente vale per l'interpretazione della legge, perché si tratta dei lavori preparatori, ritiro il mio emendamento. (S224_16.10.07)

'Mr President, if there is such a statement, which evidently applies to the interpretation of the law, since it deals with preliminary work, I withdraw my amendment.'

27. Inoltre, sarebbe utile poter quantificare una previsione che, a nostro avviso, potrebbe essere anche alternativa alla misura che qui viene individuata, perché, certamente, le risorse che perverranno attraverso quella disposizione di legge saranno molto rilevanti. (S374_28.09.10)

'Moreover, it would be useful to make a projection which, in our view, might also be an alternative to the measure identified here, because, certainly, the resources that will be obtained through that legal provision will be very significant.'

28. [...] ritengo $[\ldots]$ che l'indisponibilità del relatore a valutare una riformulazione, $[\ldots]$, sia stata un'occasione persa, perché evidentemente c'era la possibilità di riformulare la proposta emendativa [...]. (S224_16.10.07)

'I believe [...] that the speaker's unwillingness to consider a reformulation, [...], was a missed opportunity, because evidently there was the possibility of reformulating the proposed amendment [...].'

29. Un Governo così inefficiente e decadente trascina il Paese nella decadenza: inequivocabilmente, infatti, è un Paese in difficoltà quello che emerge dalla classifica mondiale della competitività [...]. (S258_14.12.07)

${ }^{13}$ See also example (2) at the beginning of this paragraph. 
'An inefficient and decadent government drags the country into decadence: unequivocally, in fact, the world competitiveness rankings our Country appears to be in a difficult situation.'

The most commonly used strategy to construct one's argumentative moves is to combine several adverbs and/or adverbial locutions into a single complex sentence. Example (30) includes two related adverbs focusing on the same propositional content; their sequence is a crescendo of certainty (or, if you prefer, of minor uncertainty). In example (31) too, we observe two related adverbs, but in this case they refer to two different dimensions: indubbiamente ('undoubtedly') refers to a, let's say, rational (or logical) dimension, while ovviamente ('obviously') refers to the common sense dimension (cf. Bertuccelli Papi 1989). Finally, example (32) contains an adversative structure with an adverb in the main clause and an adverbial locution in the adversative clause (senz'altro can be translated as 'surely'). It can be interpreted as an attempt to reconcile opposite positions: the speaker recognises, before the listeners, that the text can be improved and, at the same time, asks them to confirm the fact that the text was improved compared to the original one.

30. Per i 30 euro si assisteva forse e molto probabilmente a spese che tra procedura, accertamento e riscossione superavano ampiamente quanto incassato. (S623_18.04.2012)

'In order to get the 30-euro refund, there were perhaps and most likely costs that [...] far exceeded the amount of cash collected.'

31. Indubbiamente - e ovviamente - bisognerebbe fare dei testi unici, [...] (S673_26.07.12) 'Undoubtedly - and obviously - one should make a single text, [...]'

32. Il testo è certamente perfettibile, ma è senz'altro migliorato dal primo passaggio alla Camera. (S196_24.03.2014)

'The text can certainly be refined, but it has surely improved since the first passage to the Chamber.'

I have concluded the analysis of epistemic adverbs focusing on some particularly interesting uses, in which the propositional content affected by the adverb is not only ovvio ('obvious') but also, in a way, dovuto ('due'). The first two examples include the President's speeches: in (33), the President takes the floor to inform the Assemblea on the possibility of a change in the agenda for the following sessions as requested by some deputies; in (34), the President replies to a parliamentarian who has asked for a change in the sequence of the topics under discussion. ${ }^{14}$

33. Ovviamente, sarà cura della Presidenza assicurare un'organizzazione dei tempi adeguata all'importanza del tema in discussione. (S230_24.10.07)

\footnotetext{
14 The parliamentarian's speech and the reply by the President were therefore not planned, but they are still interactions provided for by the Rules of Procedure. The difference between planned and unplanned speeches, even if provided for, lies mainly in the way the President gives the floor and does not necessarily affect the degree of planning of the speech. More specifically, in a debate with planned speeches, the President gives, in sequence, the floor to the deputies who are entitled to speak without interruption using the formula $\grave{E}$ iscritto a parlare l'Onorevole $x$. Ne ha facoltà 'Mr./Mrs. $\mathrm{x}$ is entitled to speak. He/She takes the floor'. In an unplanned speech, the deputy him/herself asks for the floor (using the formula Chiedo di parlare 'I would ask you for the floor') and the President may either give the floor or not (the formulas can be A che titolo? 'In what capacity?', or simply Ne ha facoltà 'You are entitled to do it').
} 
'Obviously, it will be the President's responsibility to ensure an organisation appropriate to the importance of the issue under discussion.'

34. Onorevole Baldelli, evidentemente l'ordine è quello stabilito in sede di Conferenza dei presidenti di gruppo. (S456_31.03.11)

'Mr Baldelli, evidently the order is the one established during the Conferenza dei presidenti di gruppo.'

The organisation of the debate, both from the point of view of the time for each parliamentarian's speech and that of the number of sessions devoted to discuss a certain topic, is established by the Rules of Procedure and entrusted to the President. Therefore, in (33), the fact that the President shall be in charge of it is not obvious but mandatory. If ovviamente referred exclusively to the propositional content, the President, in some ways, would "state the obvious". My interpretation is that the adverb serves more as a reminder for deputies, also in order to avoid parliamentarians' speeches, which might want to discuss the timing. In other words, (33) can be restated as Ricordo ai deputati che è compito della Presidenza organizzare... ('I remind the deputies that is the President's responsibility to organise...'). Furthermore, the adverb evidentemente ('evidently') in (34) can be restated in the same way, i. e. as a remainder. In this case, though, I perceive an ironic tone as well, due to the fact that the reminder is not preventative but occurs after Mr Baldelli's speech to request a change in the agenda of the session in progress: Le ricordo onorevole Baldelli, che l'ordine è stabilito dalla Conferenza, $e$ quindi lei non ha il potere per chiedere un cambiamento ('I remind you, Mr Baldelli, that the order is established by the Conferenza, hence, you are not entitled to ask for a change').

The last example contains a parliamentarian's explanation of vote.

35. Innanzitutto, durante la discussione di questo provvedimento abbiamo avuto [...] la dimostrazione, anche se non ce n'era bisogno, della sovranità limitata di questa Camera rispetto al Senato. Ovviamente, il nostro Presidente ha eccepito l'inammissibilità di molte proposte emendative sulla base dei criteri previsti dal regolamento; sappiamo perfettamente che esse saranno riproposte nell'altro ramo del Parlamento e quindi le ritroveremo in seconda lettura alla Camera. (S101_31.01.07)

'First of all, during the discussion of this bill, we had [...] evidence, [...], of the limited sovereignty of this Chamber over the Senate. Obviously, our President refused the inadmissibility of many of the proposed amendments on the basis of the criteria set out in the Regulation; we know perfectly that they will be reposted in the other branch of Parliament and then we will find them in second reading in this Chamber.'

The fact that the President of the Chamber refused the inadmissibility granted by the Senate is something due, as the denial is based on what the Rule of Procedure sets forth; in other words, the President could not have acted otherwise. If ovviamente ('obviously') only referred to the denial itself, the adverb would be somewhat inadequate, because it would reduce the strength of the propositional content. In other words, it would have been more suitable to use a modal adverb such as necessariamente ('necessarily'), or even a deontic modal adverb such as $o b$ bligatoriamente ('compulsory'). In my opinion, the adverb serves to clarify the obviousness not of the President's behaviour but of the fact that the President behaved exactly as he had to and, consequently, in line with the Rules of Procedure and consequent expectations. In (35), 
ovviamente plays a similar role to an evaluative adverbs and could be restated as giustamente ('justly') or coerentemente ('coherently'). From an argumentative point of view, the use of ovviamente as opposed to an evaluative adverb makes it possible to provide a more objective basis to the judgement, and can be used to interrupt since the beginning or, at least, to make it more difficult to take a position that considers that behaviour to be unfair/incorrect/inconsistent. Subject to the conditions laid down in the Rules of Procedure, the President could only refuse the Senate's inadmissibility, and the fact that he behaved that way is so obvious that there is no need to question it.

\section{$5 \quad$ Evaluative and Speech Act Adverbs}

In general (and excluding correttamente 'correctly'), adverbs belonging to these two categories cause far fewer problems when analysing them. Not only are there fewer of them, but they are also clearer, from a semantic and functional point of view. Below are some examples showing how they are used in parliamentarians' speeches: in (36-39) there are some occurrences of content-oriented evaluative adverbs; in (40-44) there are some occurrences of participant-oriented evaluative adverbs; and, finally, in (45-49) there are some occurrences of speech act adverbs (speaker-oriented adverbs in (45-48) and speech act oriented in (49)).

36. Fortunatamente sono lontani i tempi nei quali se si annunciava un terremoto c'era chi pensava di poter ridere al telefono perché stava per fare un affare [...]. (S196_24.03.14)

'Fortunately, these are no longer the times when if an earthquake was announced there was someone who thought he could laugh while on the phone because he was about to make some money $[\ldots]$ '

37. Si tratta di un'azione strategica che ha portato, cari colleghi, ad un successo senza pari, fortunatamente, nei confronti della criminalità organizzata [...]. (S403_29.11.10) 'This is a strategic action that has led, dear colleagues, to unparalleled success, fortunately, with regard to organized crime [...].'

38. Noi sappiamo che questo può avvenire e in molti casi avviene, e avviene positivamente; ma disgraziatamente sappiamo anche quante volte questo non avviene. (S196_24.03.14) 'We know that this can happen and in many cases it happens, and it happens positively; but regrettably we also know how many times this does not happen.'

39. Sfortunatamente temiamo che da oggi questo Governo sia ancora meno capace di fornire risposte adeguate anche ai problemi della giustizia. (S268_17.01.08)

'Unfortunately we fear that from now on this Government will be even less able to provide suitable answers to justice-related problems.'

40. Giustamente, [...], i cittadini perdono fiducia nelle istituzioni e in chi le rappresenta. (S229_23.10.07)

'Justly, [...], citizens no longer trust institutions and those who represent them.'

41. "Italianamente" parlando, non si tratta dello straordinario inteso come effettiva esigenza di lavoro suppletivo che, giustamente, viene retribuito anche in maniera maggiorata, ma [...]. (S226_18.10.07) 
"Italianamente parlando"15, overtime does not mean an actual need for supplementary work, which, justly/fairly, is paid even more, but [...].'

42. Abbiamo letto anche il documento del Consiglio superiore della magistratura che, correttamente, ha voluto licenziarlo dopo la fase conclusiva del provvedimento. (S710_29.10.12)

'We have also read the document of the Consiglio superiore della magistratura which, correctly, wanted to dismiss it following the final phase of the measure.'

43. Parliamo di un'industria che fornisce munizionamento al Ministero della difesa e poi partecipa - come correttamente fanno tante altre aziende di questo tipo - a gare internazionali per ottenere commesse. (S225_17.01.07)

'We are talking about an industry that provides ammunitions to the Ministry of Defence and then - as correctly do so many other companies of this type - participate in international competitions to win contracts.'

44. Dunque, responsabilmente non fermeremo il processo riformatore; tuttavia, non rinunceremo alle nostre idee e valutazioni. (S228_22.10.07)

'Therefore, responsibly we will not stop the reforms; however, we will not give up on our ideas and positions/opinions.'

45. Francamente, non capisco le argomentazioni esposte poc'anzi, secondo le quali dovremmo essere preoccupati in quanto non riusciamo ad esportare molte armi in tutto il mondo. (S224_16.10.2007)

'Frankly, I do not understand the above-mentioned arguments, whereby we should be concerned because we cannot export many weapons around the world.'

46. Allo stesso modo, anche l'articolo 17 [...] tratta di un argomento che francamente non sembra abbia a che fare con la pubblica amministrazione. (S224_16.10.2007)

'Likewise, article 17 [...] also deals with a subject which frankly does not seem to have anything to do with public administration.'

47. Sinceramente, ministro Chiti, la ringrazio per la sua presenza e per la sua cortesia. (S101_31.01.2007)

'Sincerely, Minister Chiti, I would like to thank you for your presence and your courtesy.'

48. È certo che, se questo è il risultato di questo Governo, sinceramente la delusione è profonda, [...]. (S623_18.04.12)

'It is certain that, if this is the result of this government, sincerely the disappointment is profound, [...].'

49. Brevemente riassumerò il testo del provvedimento [...] (S196_24.03.2014)

'Briefly I am going to/will sum up the the text of the bill/measure'

\footnotetext{
15 Please note the use of "italianamente parlando" (literally: 'speaking in an Italian way'), an idiosyncratic neologism which, of course, has nothing to do with il parlare in italiano ('to speak Italian'). It is used with a function similar to tecnically/linguistically speaking, that is to say, following Prandi's classification, as domain adverbial locutions. What the speaker is saying is: 'the meaning of straordinario ('overtime') is normally/should be... but in Italy it means...'.
} 
Similar to what has been noted for epistemic adverbs, in several cases evaluative and speech act adverbs occur in combination. In (50), an evaluative participant-oriented adverb (giustamente 'justly') occurs in relation to an evalautive event-oriented adverb (fortunamente 'fortunately'). In (51), however, giustamente ('justly') relates to an evaluative participant-oriented adverbial locution (con solennità [literally: 'with solemnity']). In (52), three different adverbs co-occur in three different clauses: the epistemic adverb naturalmente ("naturally') occurs inside a parenthetical clause, while the event adverb normalmente (considering normally as a synonym for solitamente 'usually') and the evaluative participant-oriented adverb giustamente ('justly') occur in two different relative clauses.

50. Allo stesso tempo, in questa Europa che giustamente e fortunatamente sta diventando una unione continentale, ci sono Stati non membri dell'Unione europea che partecipano ad alcune delle sue più grandi realizzazioni. (S265_14.01.08)

'At the same time, in this Europe that rightfully and fortunately is becoming a continental union, there are non-EU member states that participate in some of its greatest achievements.'

51. [...] il Presidente della Camera ha inteso ribadire, giustamente e con solennità, i problemi che nascono dalla differenza regolamentare tra Camera e Senato [...] (S101_31.01.2007)

'[...] the President of the Chamber intends to reaffirm, justly and with solemnity/solemnly, the problems arising from the difference between the Chamber's Rules of Procedure and the Senate's Rules [...]'

52. Infine - è l'ultimo punto che voglio affrontare, ma ve ne sarebbero naturalmente molti altri - vi è un aspetto che normalmente viene sottovalutato e che giustamente la risoluzione del Consiglio d'Europa riprende e riguarda la questione della disuguaglianza. (S228_22.10.07)

'Finally - this is the last point I want to address, but there would be naturally many others - there is an aspect that is normally underestimated and that justly the Council of Europe resolution takes on board and this [underestimated] aspect deals with the issue of inequality.'

Considering that we mainly deal with spoken texts, for both speech act and evaluative participant-oriented adverbs, it is particularly interesting to observe the "communication verbs" they co-occur with (Biber et al. 1999: 362). In these texts, brevemente ${ }^{16}$ usually occurs with communication verbs like intervenire, illustrare, concludere, richiamare and ricordare ('intervene', 'illustrate', 'conclude', 'recall' and 'remember'). Normally, the adverb occurs after the verb or between the modal or the auxiliary verb and the lexical verb, in structures similar to (53). On the other hand, francamente and sinceramente are much more common without communication verbs, and when they occur with one it is usually with the verb dire ('say').

53. [...] un lavoro che [...] è servito a chiarire alcune cose, che vorrei brevemente richiamare e che sono presenti in quel testo. (S225_17.10.2007)

\footnotetext{
16 We have to remove 9 out of the 70 occurrences of brevemente ('briefly') where it occurs with the verb sospendere ('suspend'): [...] ritengo opportuno [...] sospendere brevemente la seduta (S226_18.10.2006) [I consider it appropriate [...] to briefly suspend the session].
} 
'[...] a job that $[\ldots]$ has served to clarify some of the things I would like to briefly recall and that are present in that text.'

Just like brevemente, giustamente co-occurs with communication verbs such as dire/parlare, affermare, ricordare, richiamare, sottolineare ('say', 'affirm', 'remember', 'recall', 'emphasise'). As an evaluative adverb, its function is to express a judgement on the propositional content of what others have stated. In argumentative texts, in order to support one's opinion/position, the reference to similar opinions/positions is crucial; in this genre (i.e. parliamentarians' speeches) the intertextual references are often accompanied by adverbs that emphasise their correctness (54-56). On the other hand, in (57) the adverb is used differently. The example, which is part of the sub-event parliamentary question, arises from the answer of Mr Padoan, the Minister of Economy and Finances, (i. e. it follows the explanation of the question to the Assemblea by Mr Pagano); therefore, it is important that the Minister could explain and justify the choices made without fuelling disagreement. Judging Mr Pagano's words as correct and using indipendentemente ('independently') serve to mitigate the form of the expression, whose content, in substance, can be restated as quello che ha detto non c'entra, anche se è giusto ('what you have said is not relevant; it is right, though').

54. Occorre andare oltre, prevedere degli interventi legislativi correttivi e arrivare ad una legge ad hoc, come giustamente ha detto la CEI, come giustamente ha detto la Chiesa, che si è dimostrata quella con la posizione più equilibrata e più corretta. (S101_31.01.07) 'It is necessary to go further, to provide for corrective legislative actions and to come to an ad hoc law, as the CEI justly affirmed, as the Church justly affirmed, which has proved to be the most balanced and correct position.'

55. Dobbiamo fare in modo che si recuperi quella credibilità che le istituzioni hanno perso a causa di interventi [...] che hanno fatto perdere - come giustamente sottolineava, qualche secondo fa, la collega Bandoli - quella dignità che una regione deve avere. (S264_09.01.08)

'We must ensure that the credibility that institutions have lost due to actions [...] that have caused - as Mrs Bandoli justly pointed out, a few seconds ago - the loss of that dignity a Region must have.'

56. Giustamente, signor ministro, lei ha parlato di beni indisponibili anche nell'attività legislativa. (S101_31.01.2007)

'Justly, Mr Minister, you have talked about [...].'

57. E, questo, onorevole Pagano, indipendentemente dai risultati che giustamente lei ci ricorda. (S334_19.11.14)

'And, this, Mr Pagano, independently from the results that you justly remind us.'

Correttamente ('correctly') too co-occurs in six cases with communication verbs, but only in (58) and (59) is it used in a way similar to giustamente ('justly'). In (60), it is used with the meaning of 'in accordance with what is written' (with a meaning similar to fedelmente 'faithfully' or, even better, alla lettera 'literally', since we are dealing with legal texts). The last three cases are more problematic: in (61) and (62), it seems that the adverb can be restated as secondo quanto previsto dalla procedura ('according with the Rules of Procedure'). The President is in charge of reporting to the Assemblea what happens during the Conferenza, and 
the member speaking in (61) has no elements to judge whether what the President has said is right or not. Similarly, in (62), it would be strange if the speaker referred to the fact that the contents of a bill she has just listened to are correct. In (63), the interpretation is doubtful. On the one hand, it could be interpreted as secondo quanto previsto dalla procedura ('according with the Rules of Procedure'). On the other hand, the member might refer to the fact that the contents expressed by the Government representative are correct. Since the discussion relates to a parliamentary question, and even if the member is different from the one who posed the question, the fact of asking to speak leads to the assumption that he knows the matter and, thus, the normative framework.

58. Mi suggeriscono correttamente di ripetere quanto stavo dicendo perché non è stato ascoltato. (S456_31.03.11)

'They suggest correctly that I repeat what I have just said because it was not listened to (=the others Deputies were not listening)'

59. Tale zona è interessata da una mega-operazione speculativa che - come correttamente ha affermato il sottosegretario D'Andrea - riguarda 131 mila metri quadrati di specchio d'acqua [...] (S226_18.10.07)

'This area is affected by a speculative operation which, as correctly stated by D'Andrea, is about 131,000 square feet of water [...]'

60. [...], all'articolo 21 vi sono scritte le stesse cose [...] dell'articolo 2, punto 7, del Trattato di Amsterdam - che avrebbe dovuto essere citato correttamente nel provvedimento in discussione [...]. (S260_18.12.07)

'[...], article contains the same things as Article 2, point 7, of the Amsterdam Treaty which should have been quoted correctly during the discussion of this bill/measure [...]'

61. Signor Presidente, prendiamo atto della decisione del Governo che - come lei ha correttamente ricordato poco fa - è stata annunciata nella Conferenza dei presidenti di gruppo [...]. (S261_19.12.07)

'Mr President, we take note of the Government's decision that - as you have correctly recalled earlier on - has been announced at the Conferenza dei presidenti di gruppo [...]'

62. I relatori del disegno di legge ne hanno correttamente illustrato il contenuto, che è molto vario; [...] (S169_30.04.09)

'The rapporteurs for this bill have correctly illustrated its content, which is very varied; $[\ldots]$ '

63. La ringrazio per aver fornito, all'inizio del suo intervento, un riferimento al quadro normativo complessivo e a tutta una serie di adempimenti che devono essere osservati e che, nel caso specifico, sulla base di quanto lei ha correttamente riferito, sono stati rispettati. (S225_17.10.07)

'I would like to thank you for providing, at the beginning of your speech, a reference to the overall normative framework and to the requirements that must be observed and which, in this specific case, on the basis of what you have correctly reported, have been respected.'

Example (60) allows for considering a theoretical aspect I only referred to, that is to say, the classification based on the syntactic position of the adverbs. Actually, in (60), correttamente 
does not express an individual view on some behaviour (i. e. it is not an evaluative adverb), but it functions as a verb's modifier, specifying the way the article should be referred to. However, one cannot state that all the adverbs change their semantic-syntactic function when occurring after a verb. In (64), it is clear that, even if it is placed after a verb, sinceramente ('sincerely') performs its semantic effect in the sentence that follows the colon, i. e. on the propositional content of dire anticipated by the pronoun lo. In other words, dirlo sinceramente (literally, 'say it sincerely') can be considered as an adverbial locution similar to per essere sincero ('to be honest') o sinceramente parlando ('sincerely speaking').

64. Lo dico sinceramente: innanzitutto, credo che il centrodestra debba rilanciare il tema dell'Assemblea costituente [...]. (S229_23.10.2007)

'I say it sincerely: first of all, I believe that the right-wing party should revive the theme of the Assemblea costituente [...]'

Other cases can be more ambiguous and described differently. For example, in Lonzi (1991: 403) the following example is illustrated with its two possible interpretations: if interpreted as $\left(a^{1}\right)$, intelligentemente ('intelligently'/'cleverly') would be an adverb of manner; if interpreted as $\left(\mathrm{a}^{2}\right)$, it would be a sentence adverb, in particular a "participant-oriented adverb" (i. e. an adverb focusing on the subject commenting on his/her behaviour).

(a) Ha illustrato intelligentemente i passaggi più difficili della teoria

'S/he intelligently/cleverly illustrated the most difficult points of the theory'

$\left(a^{1}\right)$ illustrare in maniera intelligente i passaggi più difficili della teoria

'to illustrate with intelligence the most difficult points of the theory'

$\left(\mathrm{a}^{2}\right)$ illustrare i passaggi più difficili della teoria, agendo intelligentemente

'to illustrate the most difficult points of the theory, acting intelligently'

This also applies to (65) and (66), where giustamente ('justly') can be interpreted either as a verb's modifier or as an evaluative adverb. In both examples, this adverb can be restated as in modo giusto ('in the right way'), or it can be interpreted as an assessment on the propositional content: in (65), 'it is right to advise the abolition of a part of article 9'; in (66), 'it is right that the police claim a salary increase'. Similarly, in (67) the giustamente e legittimamente (literally 'justly and legitimately') can be restated as 'in the right way and in fairness', or can be interpreted as 'I consider that is just and fair that the Presidency [...]' etc.

65. L'emendamento Marone [...] propone giustamente di sopprimere il sesto comma dell'articolo 9 (S225_17.10.07)

'Marone's amendment [...] justly suggests to delete the sixth paragraph of Article 9'

66. [...] fuori da questo Palazzo per più di una settimana c'erano banchi e banchetti di democratiche rappresentanze di polizia che lamentavano giustamente l'adeguamento salariale bloccato da cinque anni (S294_19.09.14)

'[...] outside this Palazzo for more than a week there were stands with police representatives who justly complained about the five-year wage adjustment'

67. Non riteniamo questo un fatto straordinario, ma solo che la Presidenza abbia legittimamente e giustamente applicato il regolamento. 
'We do not consider this to be extraordinary, but only that the Presidency justly and legitimately has applied the Rules of Procedure.'

\section{Conclusions}

The main purpose of this paper was to provide a first general (and, hence, simplified) description of the way epistemic, evaluative and speech act adverbs are used in a specific genre of political speech which is an argumentative text-type, and thus a favourable environment for the use of the above (sub-)classes.

As has been described, epistemic adverbs expressing doubt and certainty are mainly used to express the certainty of one's opinion on a specific topic, of one's positions and expectations, and of one's future or present behaviour. According to their semantic meanings, indubbiamente ('undoubtedly') is used to qualify opinions based on objective factual data, whereas probabilmente ('probably') is used more frequently in sentences that try to interpret someone else's behaviour and foresee the consequences of decisions and/or facts. As for adverbs referring to the source of knowledge, it seems that evidentemente ('evidently') behaves as probably does, in that it occurs more frequently in sentences whose propositional content communicates an interpretation of some fact or behaviour. On the other hand, it seems that ovviamente ('obviously') occurs in positions that are more similar to those of certamente/sicuramente ('certainly'/'surely'), i. e. in sentences whose propositional content expresses facts and/or personal opinions, state the obviousness of a personal position, or an expectation and some future behaviour.

When they occur in causal structures, epistemic adverbs are used to strengthen one's position/opinion. When an epistemic adverb appears in the main clause, the causal clause is used to explain both the reason underlying the statement and its certainty or evidence. When the adverb occurs in the causal clause, however, the certainty or evidence underlying the reason is emphasised. Similarly, evaluative participant-oriented adverbs - such as giustamente and correttamente ('justly', 'correctly') - can co-occur with communication verbs to strengthen the speaker's opinion/position by recalling other people' statements and emphasising their correctness.

When they occur in adversative structures, epistemic adverbs are used to mitigate disagreements. When an adverb occurs in the main clause, its function is to weaken the potential disagreement even further. When, however, it appears in adversative clauses, adverbs strengthen a disagreement by giving it the basis of certainty or evidence.

Since what has been presented so far is the outcome of a preliminary analysis, further consideration should be given to several aspects, which I briefly describe as suggestions for future analysis.

Firstly, an accurate analysis of all the examples would be necessary, including all epistemic adverbs, and adverbial locutions. This analysis would require: a) a more detailed description of the propositional contents of clauses where adverbs occur; b) a distinction between adverbs occurring in independent clauses, subordinate clauses and coordinate clauses. The analysis, including adverbial locutions, would provide a more accurate idea of the frequency not only 
of each of the three (sub-)classes but also of the different semantic areas in which adverbs have been subdivided.

Secondly, this initial analysis has not enabled to find a correlation between the various forms of communicative sub-events and differences in the use of adverbs. Nonetheless, this does not mean that there are no correlations. To verify this, it would be necessary to build sub-corpora reflecting the different communicative sub-events that might occur within the communicative event of the Assemblea, adding other texts so that the sub-corpora could be comparable. The subdivision in sub-corpora would enable to observe whether the difference in speech form implies differences: a) in the total frequency of adverbs; b) in the category of adverbs used; c) in the type of most common adverbs; d) in the type of propositional content affected by adverbs.

Finally, it would be important to analyse these adverbs using larger portion of texts, as well as including other linguistic elements that convey the modality in the analysis, such as the modal verb potere, the parenthetical verbs io penso/credo/ritengo, the conditional mood, etc. (cf. Venier 1991). This would enable to analyse how co-occurrence of all these elements contributes to building argumentative moves, and would provide a better description of these three categories.

\section{Corpus/Corpora}

CAMERA EN (2015). http://en.camera.it/4?scheda_informazioni=8 [October 2018].

CAMERA IT (2015). http://www.camera.it/leg17/207 [October 2018].

UK PARLIAMENT. http://www.parliament.uk/site-information/glossary/floor-of-the-house/ [October 2018]

\section{References}

Bertuccelli Papi, Marcella (1989): «Avverbi frasali e atteggiamenti del parlante». Quaderni di semantica 20/2: 333-358.

Biber, Douglas et al. (1999): Grammar of spoken and written English. Harlow: Longman.

Caffi, Claudia (2009): «Lezione VI». In: Caffi, Claudia (ed.): Pragmatica. Sei lezioni. Roma, Carocci: $115-136$.

Conte, Maria-Elisabeth (1999): «Metatestualità». In: Conte, Maria-Elisabeth (ed.): Condizioni di coerenza. Ricerche di linguistica testuale. Alessandria, Edizioni dell'Orso: 47-50.

De Mauro, Tullio (2001): Il dizionario della lingua italiana per il terzo millennio. Torino: Paravia. https://dizionario.internazionale.it/ [01.10.2017].

De Cesare, Anna-Maria (2003): «Les adverbes italiens davvero et veramente: Propositions de description ». Revue Romane XXXVIII/1: 29-52.

De Cesare, Anna-Maria (2016): «Per una tipologia semantico-funzionale degli avverbiali. Uno studio basato sulla distribuzione informativa degli avverbi (in -mente) negli enunciati dell'italiano parlato». Linguistica e Filologia 36/2016: 27-68.

Dik, Simon C. et al. (1990): "The hierarchical structure of the clause and the typology of adverbial satellites". In: Nuyts, Jan/Bolkestein, Machtelt A./Vet, Co (eds.): Layers and levels of representation in language theory. Amsterdam/Philadelphia, Benjamins: 25-70. 
Halliday, Michael A. K (1970): “Linguistic structure and linguistic function”. In: Lyons, John (ed.): New horizons in linguistics. London, Harmondsworth: 140-165.

Hatim, Basil (1984): "A text-typological approach to syllabus design in translator training". The Incorporated Linguist 33/3: 146-149.

La Forgia, Francesca (2006): «Alcune osservazioni sui focalizzatori». Studi Italiani di Linguistica Teorica e Applicata 35/2: 359-385.

Lonzi, Lidia (1991): «Il sintagma avverbiale». In: Renzi, Lorenzo/Salvi, Giampaolo (eds.): Grande grammatica italiana di consultazione. Volume II. Bologna, Il Mulino: 341-412.

Merlini Barbaresi, Lavinia (1987): "Obviously and certainly: Two different functions in argumentative discourse". Folia linguistica 21: 3-34.

Prandi, Michele (2004): The building blocks of meaning. Amsterdam/Philadelphia: Benjamins.

Prandi, Michele (2006): Le regole e le scelte. Introduzione alla grammatica italiana. Torino: UTET.

Prandi, Michele (2007): «Avverbi di collegamento e congiunzioni». In: San Vicente, Felix (ed.): Partículas/Particelle. Estudios de lingüística contrastiva español e italiano. Bologna, CLUEB: 89-104.

Ramat, Paolo/Ricca, Davide (1998): "Sentence adverbs in the languages of Europe". In: Auwera, Johan van der (ed.): Adverbial constructions in the languages of Europe. Berlin/New York, Mouton de Gruyter: 187-275.

Santulli, Francesca (2005): Le parole del potere, il potere delle parole. Retorica e discorso politico. Milano: Franco Angeli.

Serianni, Luca (1989): Grammatica italiana. Italiano comune e lingua letteraria. Torino: UTET.

Treccani: Dizionario della lingua italiana. www.treccani.it/vocabolario/ [01.10.2017].

Venier, Federica (1991): La modalizzazione assertiva. Avverbi modali e verbi parentetici. Milano: Franco Angeli. 